\title{
ISLAM AND THE DEVELOPMENT OF DEMOCRATIC OPPOSITION IN CENTRAL ASIA
}

\author{
Elmira Akhmetova*
}

\begin{abstract}
This article provides a brief study of democracy in the five Central Asian countries, i.e. Kyrgyzstan, Kazakhstan, Uzbekistan, Tajikistan and Turkmenistan. It suggests that the expected democratisation of Central Asia failed to occur due to the region's internal conditions, which can be termed the 'classic colonial syndrome', in addition to several international factors. The Central Asian countries did not have the potential to find their own way in the international arena, simply maintaining their traditional Soviet way of rule under the new name of 'democracy'. The paper also finds that the Central Asian approach to Islam at both state and individual level is a crucial tool of identity construction as well as an instrument of authority, control and suppression of political opposition. Yet, Islam played almost no role in the failure of democracy in the region. This article states that the application of instruments of democracy alone cannot make nations democratic or provide well-being and justice for the people. Democracy is about sets of values and principles aimed at achieving good governance. Thus, democracy should be considered as a tool and structure on the path of achieving societal well-being, rather than as the main objective of governance.
\end{abstract}

Keywords: Islam and Democracy, Democratic Opposition, Central Asia, Human Rights, Democratisation.

\section{Introduction}

The end of Soviet dominance in Central Asia in 1991 was applauded by the international community as representing the triumph of Western liberalism and the beginning of democracy and progress in the region. The five resultant states emerged from the ruins of the Soviet Union in the name of liberalism and progress: Uzbekistan, Kazakhstan, Kyrgyzstan, Tajikistan and Turkmenistan. Totalitarian communist parties were transformed into presidential parties, promising the start of democratisation. Yet, the UK-based Economist Intelligence Unit's Democracy Index observes that, after twenty-five years of independence from Russia, Central Asian countries are still in transition, showing little progress towards democratisation. This Democracy Index is based on five categories: electoral process and pluralism, civil liberties, the functioning of government, 
political participation, and political culture. Among the five Central Asian countries, only Kyrgyzstan is classified as a hybrid regime (ranked number 95 of 167 countries). In 2017, Kyrgyzstan experienced its first peaceful, orderly and democratic transfer of power, when Sooronbai Zheenbekov was elected as the new president. ${ }^{1}$ Other Central Asian countries, however, are still classified as authoritarian. Kazakhstan is number 141 in the Democracy Index list, while the other three countries round out the bottom 10, with Uzbekistan at 158, Tajikistan at 159 and Turkmenistan at 162 .

Interestingly, all five Central Asian countries are Muslim-majority states, although levels of religiosity vary between each country. The underlying question here is whether Islam has acted as a barrier to democracy in Central Asia? Should the failure of democratisation in Central Asia be analysed within the framework of the clash of civilisations and culture? More precisely, how to define being 'democratic'? Is it a system which perfectly follows the Western model of democracy or merely a set of values and principles that contribute towards the well-being of all citizens?

Interestingly, definitions of democracy are contested, with an ongoing and lively debate surrounding the subject. It is commonly agreed that to be recognised as 'democratic', systems need to realise a number of aspects, such as: (1) inclusiveness: all members of a political community have the right to political participation; (2) popular control: decisions rest with the political community as a whole; (3) considered judgement: individual and collective decisions should be based on people being adequately informed and understanding the positions of others; and (4) transparency: decision-making should be open and accountable. These aspects, along with other practical elements, such as "a strong civil society, an active and unrestricted press, a strong and fair legal system, checks and balances on power and free and fair elections," make a system democratic. ${ }^{2}$

There is no consensus concerning how to measure levels of democracy. This paper, however, proposes that democracy be about much more than representative government or elections. It should be reviewed as a set of values and principles that rely on the fundamental doctrines of egalitarianism, pluralism and equal human rights. Within that context, the inherently democratic spirit of Islam emerges, as a religion of tolerance, pluralism, justice, and human rights. ${ }^{3}$

\section{Islam, Democracy and Opposition}

The main focus of social theorists in the nineteenth century was the differentiation of what is religious and what is not. Today, the fundamental question concerns 
being religious or more religious, thus positioning the concept of religious fundamentalism as a negative pattern that opposes the moderate manifestation of religion in public life. Whether democracy is compatible with Islamic principles is commonly discussed within this dichotomous framework. The sudden end of Cold War politics resulted in a serious vacuum that required the creation of a new enemy on the basis of an alternative division of the world along cultural and religious lines. Within this context, the concept of a 'clash of civilisations' was suggested as an alternative paradigm in the post-Cold War era. The contemporary world order, consequently, is mainly based on conflict and severe attention to differences, with Islam becoming an enemy of everything related to progress, well-being, development, peace and security.

The compatibility of Islam with modern democracy is a multifaceted topic. Very often, especially after the tragedy of 9/11 in 2001, Islam is considered an enemy of democratic development. Critics of the concept of Islamic democracy claim that Islam and secularism, which includes democracy as one of its fundamental components, in addition to liberalism and constitutionalism, are contradictory forces, that Islam is based on theocracy and thus incompatible with secularism and democracy. It is also claimed that Muslim culture lacks the liberal social attitudes of democratic societies. In 1990, Bernard Lewis published a seminal essay in Atlantic magazine, entitled "The Roots of Muslim Rage," which arguably defined how an entire generation of post-Cold War thinkers perceived the Muslim world. Lewis believed that the religion of Muhammad, instead of being a private matter, is essentially political. ${ }^{4}$ The core of the 'incompatibility theory', consequently, is founded on the assumption that "Islam is inherently a political religion which does not leave any space for the open discussion and, thus, prevents burgeoning of democracy." "If secularisation, modernisation and democracy are inseparable, yet Islam is "secularism-resistant," then as Samuel Huntington declares, Islam is the major reason for democratic failure in the Muslim world. ${ }^{6}$ Indeed, some conservative Muslim thinkers have argued that Islam and democracy are incompatible because of the Islamic concept of the absolute sovereignty of God. For them, as John Voll precisely pointed out, the idea of the sovereignty of the people contradicts this fundamental principle. ${ }^{7}$ Also, in Islam the law which has been defined by God and the Shari'ah cannot be altered by elected parliaments, as in a democratic system. The concept of parliaments as a source of law is therefore seen as blasphemous. ${ }^{8}$

Others, however, claim that Islam is a religion of human rights, tolerance, pluralism and justice. The supporters of this idea of an inherently democratic Islam argue that the concepts of liberalism and democratic participation are already present in Islam. ${ }^{9}$ Rashid al-Ghanoushi, for instance, suggests that Islamic rule is by its nature democratic, and in the conditions of the contemporary era, 
pluralistic parliamentary democracy is the ideal instrument for putting God's Shari'ah into practice. ${ }^{10}$ Commonly, supporters of this perspective endeavour to situate their discussions within a consideration of how the expression of democracy has been, is being, or could be shaped by specific Islamic legal, religious, and cultural contexts and doctrines, to demonstrate how democracy is being 'indigenised' within the Islamic world.

Hashim Kamali, for example, views a democratic system of rule as being, on the whole, acceptable to Islam. He suggests that Islam envisages a civilian system of rule, not a theocracy, "Because the head of state is elected by the people through consultation, nomination and pledge of allegiance (bay'ah), this process translates into the modern day equivalent of a popularly elected government in which the locus of authority rests with the people. The head of state is accountable to the people and subject to the court of justice, and the people have the authority ultimately to depose him in the event of flagrant violation and miscarriage of duty." 11 This opinion is based on a consideration of Islam's relative openness to other civilisations, which allows such comparisons to modern-day democracy to take place. Yet, even though the values of democracy are taken from other traditions, "no one has rights to interfere with any fundamental beliefs and principles of Islam embedded firmly in the Qur'an and Sunnah of the Prophet (PBUH) in the name of democracy." 12

Twenty-two years later after the publication of his "The Roots of Muslim Rage," Lewis, in an interview with The Islamic Monthly in 2012, highlighted that Muslims have their own traditions. He stated that, "The important point to bear in mind is that the whole Muslim tradition is totally and unequivocally opposed to autocratic and oppressive government. This is very, very clear."13 He also highlighted that Islam explicitly rejects dictatorship, with no evidence in the traditions of the Prophet (PBUH) or verses of the Qur'an to suggest otherwise. Interestingly, for Asef Bayat, the question is not whether Islam is compatible with democracy, but rather under what conditions Muslims can make it compatible. This is because, as Bayat states, "there is nothing intrinsic in Islam, and for that matter any other religion, which makes them inherently democratic or undemocratic." 14 Thus the compatibility or incompatibility of a religion, including Islam, with democracy is not a matter of mere philosophical speculation, but of political struggle. ${ }^{15}$ Human beings determine the inclusive or authoritarian thrust of religion. This idea of the decisive role of society in determining the nature of a government is discussed in the following pages with regards to Central Asia. 


\section{The Profile of Democracy in Central Asia}

Central Asia is a geographical concept, covering the ancient region of Transoxiania and the Mawarannahr (Ar. 'beyond the river') of Islamic history. The Soviet definition of Central Asia included the four republics of Turkmenistan, Kyrgyzstan, Uzbekistan and Tajikistan, while Kazakhstan stood on its own as an independent geographical location. In this study, the notion of Central Asia includes the five states that emerged from the ruins of the Soviet Union in 1991: Kazakhstan, Kyrgyzstan, Uzbekistan, Tajikistan and Turkmenistan.

After receiving their independence from Russia, these Central Asian countries faced formidable difficulties in making the transition from a totalitarian political system to a market-based economy set on the path to democracy. Indeed, as the Democracy Index reveals, none of have yet succeeded in achieving a democratic system. This section of the article provides some general information about the status of democratisation in each of the five countries, focusing on their types of government, economic well-being, the status of religious and human rights, and their electoral systems.

\section{Kyrgyzstan}

The new Kyrgyz state was proclaimed in 1991, marking the detachment of a small mountainous area from centralised Soviet rule. Independence was received with little rejoicing, as national awareness and enthusiasm for building an independent nation-state for the Kyrgyz people was barely noticeable. Compared to its neighbouring one-party states, all headed by dictators-for-life, Kyrgyzstan is today called an 'island of democracy' in authoritarian Central Asia. The overall score of Kyrgyzstan in the 2017 Democracy Index was 5.11, placing it within the category of 'hybrid regime' and number 95 of the 167 countries on the list. ${ }^{16}$ This is the best score among all the Central Asian countries. It is also better than Russia, which was ranked number 135, with an overall score of 4.41 .

In its 2015 elections, fourteenth parties ran for the Kyrgyz parliament. Yet, as Nate Schenkkan argues, Kyrgyzstan is not a democratic country following Western standards. During the 2015 election, Schenkkan observed that:

Kyrgyzstan's parties are ad hoc collections of individual leaders who use their business and family ties to deliver votes in specific cities and towns, which in exchange expect those leaders to deliver the goods. That means handing out jobs in schools and civil service, allocating state contracts as favours, and appropriating public property for private gain. The struggle for seats is a struggle for the sources of revenue - taxes, foreign assistance, and mineral wealth - that the state 
controls. What little policy talk exists consists basically of posturing, as none of the parties have implementable plans for matching income to expenditures. ${ }^{17}$

It seems political parties in Kyrgyzstan completely lack ideological and policy definition. They lack specific platforms, structure, and identities, or clear economic and political positions. Corruption is widespread in the country, repression of dissent is growing, and its democracy looks ever more unstable after twenty-seven years of independence. The country lacks sound political participation and a culture of good governance.

When Kyrgyzstan obtained its independence, it lacked unity, legitimacy and credibility. National cohesion was absent, as there was no unifying sense of identity, the Kyrgyz people being mostly tribal. Until the late 1880s, the Kyrgyz tribes were still a nomadic people, who loosely controlled a vast territory, their society operating within a flexible structure in which every family belonged to a clan group and, in turn, to a wider tribal consideration.

Under the umbrella of ethnic revival, Islam was declared part of the national heritage, although the Kyrgyz people received Islam very late. Yet, the great potential of Islam within the nation-building process, as a distinctive element of Kyrgyz identity capable of filling the ideological vacuum that emerged after the fall of the Soviet Union, has been neglected. Although religious freedom and the secular nature of the state were proclaimed during the independence of Kyrgyzstan, Islam has been utilised in a deliberate manner to promote Kyrgyz identity and legitimise authority. Throughout years of independence, as Robert Lowe observed, Islam has been employed by the state as a political tool to boost national credentials, often being hijacked to reinforce new state ideology. ${ }^{18}$

Pluralism and human rights signify levels of democracy in modern states. Kyrgyzstan is home to over eighty different nationalities, of which the main ethnic group, the Kyrgyz, comprise 73.3 percent of the total population (5.6 million according to the 2013 Census). The other two sizeable ethnic groups are the Uzbeks (around 14.6 percent) in the south, and the Russians (5.8 percent) in the north. With the disappearance of Soviet identity, these non-Kyrgyz ethnicities have found themselves stranded in a newly formed foreign land. The government has worked hard to include these various groups into the new republic, yet it has been difficult for non-Kyrgyz people to identify themselves with a state which promotes Kyrgyz culture and the legends of Manas. ${ }^{19}$ Nevertheless, relations between ethnic communities in the republic are amicable, although clashes did occur in 2010 in Kyrgyzstan's second largest city, Osh, between the two main ethnic groups, the Uzbeks and Kyrgyz. This is because the Uzbeks have been relegated to de facto second-class status. Certainly, economically the regions 
of the republic are not developing harmoniously; an increasingly impoverished south, where the Uzbeks live, has been challenged by the north's economic and political supremacy due to both clan monopoly and ethnicity issues.

\section{Kazakhstan}

Kazakhstan dominates Central Asia economically, generating 60 percent of the region's GDP, mainly through its oil and gas industry, in addition to its vast mineral resources. The Constitution of Kazakhstan positions the country as democratic and secular, a constitutional republic with a diverse cultural heritage. Yet, the very fact that the country has been ruled by a single president, 77-yearold Nursultan Nazarbayev, since its independence casts doubt upon the status of Kazakhstan as democratic and egalitarian. The President may veto legislation that has been passed by the Parliament and is also the commander in chief of the armed forces. Kazakhstan is often condemned for its history of human rights abuses and suppression of political opposition and freedom of speech. The absence of political accountability and widespread corruption is a reality. ${ }^{20}$ Kazakhstan is no longer seen as a country in transition to democracy, but as a consolidated authoritarian regime numbered 141 in the 2017 Democracy Index.

As Nurseit Niyazbekov observes, opposition is almost non-existent in Kazakhstan. Due to the regime's powerful propaganda, opponents lack popular support and are subject to intimidation. During the 2015 presidential elections, which fell short of international standards, Nazarbayev won 97.7 percent of the nationwide vote. Appeasement and propaganda, as Niyazbekov argues, were the main reasons why Niyazbekov won the hearts of population. In addition, oil and gas revenues have allowed the government to rapidly improve people's living standards and rebuild social infrastructure. ${ }^{21}$ Yet, the oil-dependent economy has resulted in migration from rural areas into larger cities and oil plants, particularly in the northern parts of Kazakhstan, thus creating economic instability in agrarian regions.

Ethnically, Kazakhs represent 63.1 percent of the total population, while ethnic Russians constitute 23.7 percent. Other large ethnic groups include Ukrainians (2.1 percent), Uzbeks (2.8 percent), Tatars (1.3 percent), Belarusians, Uyghurs (1.4 percent), Azerbaijanis, Kalmyks, Chuvashes, Poles and others. Russians are dominant in the industrial areas of the country's northern provinces. Unequal ethnic representation within the government is obvious. In 1985, Kazakhs occupied 50 percent of top posts in the republic, a figure which, by 1997, had risen to 83 percent. ${ }^{22}$ 


\section{Uzbekistan}

When Uzbekistan obtained its independence, the problems hindering its development as a nation-state differed from those affecting other Central Asian countries. Issues of ethnicity, tribalism and a weak economy undermined the path of Uzbekistan towards democracy. Today, the 2017 Democracy Index indicates Uzbekistan is an authoritarian regime, numbered 158 in the global rankings, with an overall score of 1.95 out of 10 .

The Uzbekistan constitution of 1992 calls for a secular, democratic governmental system characterised by freedom of expression, freedom of religion, and the rule of law. Yet, from 1991 until 2016, Uzbekistan has been governed by only one leader, President Islam Karimov, who built his power upon the totalitarian structure of the old Soviet-era Communist Party apparatus and bureaucracy. The government has justified its restraint of personal liberty and freedom of speech by emphasising the need for stability and a gradual approach to change, citing the conflict and chaos in other former republics as a warning example. ${ }^{23}$ Power under this one-man rule has been unevenly divided among several clans, the most powerful of which is based in Samarkand, the birthplace of President Karimov. Other clans from Fergana, Khorazm and other parts have been marginalised since independence.

Organised crime, corruption, nepotism and political repression continues to be a widespread problem in Uzbekistan. Corruption and criminal influences in the government are so intertwined that, as Saltanat Berdikeeva observes, the state has essentially institutionalised criminality and corruption, as "President Islam Karimov's entourage, which controls the entire economy, is the real mafia. All illegal businesses are done through the state, embracing industries such as oil, gas, sugar production, flour making, Internet distribution, and telecommunications, among others. There have been reported cases of illegal circulations of gold and non-ferrous metals. ${ }^{24}$

The US-based Freedom House has consistently ranked Uzbekistan near the bottom of its Freedom in the World Ranking since its independence. In its 2017 report, Uzbekistan was ranked as one of the 11 worst countries for political rights and civil liberties. ${ }^{25}$ Although authorities released some prisoners of conscience in 2017, all of whom had been jailed under Karimov, these few signs of progress are insufficient; independent journalists, activists, and political figures remain subject to harassment and prosecution at the local and national levels, with major institutional reforms yet to be enacted. ${ }^{26}$

Religious freedom is another challenging human rights issue in Uzbekistan. At the beginning of his rule, the President Karimov cautiously sought to gain credibility by appealing to Islamic sentiments while endeavouring to build a 
secular state. He considered Islam one of the major pillars upon which national identities could be constructed, yet not at the expense of the rise of any type of Islamic opposition, which could cause a substantial threat to his power. In the late 1990s, a number of show trials against alleged Wahhabis were held to demonstrate the vigour of his anti-Islamic campaign. ${ }^{27}$ The 2005 civil unrest in Uzbekistan, which resulted in several hundred people being killed in Andijon, is viewed by many as a landmark event in the history of human rights abuse in Uzbekistan.

Unlike the oil-rich Kazakhstan, Uzbekistan was not able to deliver public well-being, healthcare and the economic growth of the nation. The Soviets attempted to establish a cotton monoculture in Uzbekistan; by the end of Soviet rule, two-thirds to three-quarters of Soviet cotton was grown in Uzbekistan and accounted for 75 percent of national income, employing 40 percent of the workforce and consuming 60 percent of the republic's resources. Even today, despite a considerable drop in cotton production, Uzbekistan alone accounts for around 7-10 percent of world cotton production and 18-23 percent of world cotton exports, ranking fifth and second respectively in the world. ${ }^{28}$ Cotton remains the backbone of the Uzbek economy, leaving it reliant on food imports and keeping the region critically short of water and other environmental crises due to heavy use of fertilisers and pesticides in cotton fields.

\section{Tajikistan}

Unlike other Central Asian countries, Tajikistan's nation-building project was halted by a civil war lasting from 1992 to 1997. Many factors contributed to this war, including economic depression and intense inter-ethnic discord created during the Soviet era, as disadvantaged regions, provinces and clans defied their better-off counterparts. Mehrdad Haghayeghi believes that the determination of the Khujandi elite to retain power, having dominated both the economy and politics under Soviet rule, keeping the clans from the southern and central regions of Kulaib and Qarategin out of the decision-making process, was an important cause of this conflict. ${ }^{29}$ Although an uneasy peace was established in 1997, it did not mark the beginning of a democratic transformation. Rather, Khujandi dominance has been replaced with that of the Kulaibis. The President of Tajikistan since 1994, Emomali Rahmon, is from the Kulaibis. He was granted immunity from prosecution for life by the parliament in December 2015 and has veto power over all major state decisions and the freedom to address the nation or parliament on all matters he considers important. On 22 May 2016, a nationwide referendum approved a number of changes to the country's constitution, such as lifting the limit on presidential terms, allowing President Rahmon to stay in power for as long as he wishes. ${ }^{30}$ 
The Freedom House report 2017 observes that the Tajikistan government continues to arbitrarily limit free speech, access to information, and the right to civic organisation. Political rights and civil liberties in Tajikistan are severely restricted by the government, which constantly maintains a campaign of repression against political opposition, dissent, and criticism. ${ }^{31}$ The opposition cannot pursue their activities in the country legally. The economic situation is also worsening, with Tajikistan remaining a donor-dependent country throughout its twenty-five-year history of independence. A lack of employment opportunities has driven more than ten percent of the population to seek work elsewhere, usually in Russia. ${ }^{32}$

\section{Turkmenistan}

Turkmenistan was placed 162 in the 2017 Democracy Index list, barely edging countries like Equatorial Guinea, Syria, and North Korea. According to the Freedom House report, Turkmenistan is a "highly repressive authoritarian state where citizens' political rights and civil liberties are almost completely denied in practice. Elections in Turkmenistan are controlled by the state, ensuring nearly unanimous victories for the president and his party. Corruption is systemic, religious groups and minorities are persecuted, and political dissent is not tolerated. Numerous political prisoners remain behind bars or unaccounted for, and reports of torture and other human rights abuses are common." 33

Turkmenistan's independence was proclaimed on 27 October 1991 without any major trouble. Saparmurad Niyazov, First Secretary of the Communist Party in the Republic of Turkmenistan since 1985 and President of the Republic's Supreme Soviet in 1990, was elected as president of the newly independent country. The Communist Party disappeared, giving birth to the Democratic Party of Turkmenistan, which soon became the president's party. ${ }^{34}$ All tiny opposition parties disappeared from the outset.

The Constitution of Turkmenistan instituted a presidential system, reinforced by a personality cult surrounding the Turkmen president. His portraits and images appeared everywhere, on every note of Turkmenistan currency, on the labels of vodka bottles sold in the Muslim country, on billboards planted at intersections. School pupils were required to make a vow each day that bad thoughts about Niyazov were treasonous, with much of their time in the classroom being spent memorising The Sayings of Turkmenbashi (the chief of the Turkmens). University students, on the other hand, were required to recite his official biography before every exam. ${ }^{35}$ Since 2007, Niyazov's successor, Berdymukhammedov, has sought to replace the cult of Niyazov with his own. 
Turkmenistan guaranteed its economic independence by selling its natural gas, yet could not provide welfare for its people. The economic situation has worsened since 2016 due to low global energy prices, resulting in unpaid wages and food shortages across the country. Journalists who spread information about the economic situation face persecution and violence.

\section{Central Asia: Between Democracy and Its Soviet Heritage}

Experts and political pundits are not enthusiastic about the future of democracy in Central Asia. In 2017, for example, Casey Michel identified Central Asia as being in the democratic doldrums. ${ }^{36}$ But, what are the reasons for the failure of the foreseen democratisation of the region?

First, Central Asian countries failed to establish independent political systems and structures after obtaining sovereignty. Their post-independence political systems are all modelled on Soviet-era bureaucracy and political structures, resulting in the marginalisation of emerging vibrant political opposition. The sicknesses of corruption, organised repression, nepotism and the old patronage system still exist in Central Asian countries even after twenty-seven years of independence. In most cases, the communist parties were simply transformed into presidential parties (ironically claiming to be democratic parties), with the same legacy and tactics. All state apparatuses was inherited from Sovietism. Leaders were the students of the establishment of homo sovieticus and totalitarianism, coming directly from the Soviet nomenklatura, who only a few months before independence were still servilely repeating Moscow slogans, yet quickly "became the mouthpieces of a nationalism that was more hostile to Russia and open to the West." ${ }^{37}$ Under present conditions, there is almost no sign of an alternative opposition appearing in Central Asia. In sum, although the newly established Central Asian republics claimed to follow the path of democratisation, the governance and civil society of those countries were rebuilt within the framework of totalitarian Soviet institutions. ${ }^{38}$

A second hindrance to the post-independence democratisation of Central Asia relates to the intensification of ethnic, tribal, regional and clan divisions, which caused a civil war in Tajikistan and ethnic clashes in other states, such as the conflict between the Kyrgyz and Uzbeks in Osh in 2010. In this context, the region's governments have opted to suppress any potential political opposition at any price, thus instigating the abuse of human rights, persecution and political repression.

In fact, contemporary ethnic tensions in Central Asia are the consequence of the geographical borders artificially, but cunningly, designed during Soviet 
times to marginalise Central Asia's sizeable ethnic groups and tribes by splitting them into different geographical units. The artificial boundaries created as a result of this Soviet national-territorial delimitation in the Ferghana region of the 1920s, for instance, continue to cause many ongoing regional territorial disputes between Kyrgyzstan and Uzbekistan. Tom Everett-Health believes that "the lines drawn on maps by the Soviets during the 1920s - which were initially adopted at independence in 1991 - are being redrawn, throwing into sharp relief the importance of the original Soviet methodology, its objectives and the way in which those objectives have shaped the political and economic development of the region." 39

Third, as Oliver Roy observes, the achievement of independence in Central Asia was sudden and not necessarily desired. There was no strong historical memory of a nation lost, nor had any nationalist movements prepared the ground, as in Armenia, Georgia and the Baltic countries. ${ }^{40}$ Central Asian nationalities were Soviet inventions of the 1920s, with ethnic identities such as Kyrgyz or Kazakh not having existed previously. While there had been various manifestations of collective identity consciousness among Muslims in Central Asia, such as religious, regional or dynastic affiliations, there had been a lack of national identification. The Soviets, however, implemented nation-building projects throughout Central Asia aimed at building secular national consciousness. Imagined nationalities were created by the administrative, cultural and political habitus installed by Russian colonial power, within an entity that had no antecedents of nationhood. ${ }^{41}$

Prior to the Russian advance into Central Asia, the region was mainly under the rule of the two khanates of Khiva and Kokand, in addition to the emirate of Bukhara. The Turkmen, Kazakh and Kyrgyz communities were divided into independent tribal federations led by a single leader, under whose authority a tribal council managed the affairs of the tribe. Loyalty was to the khan or emir and to one's clan, tribe, or ethnic group. Among Uzbeks and Tajiks, Islam played a prominent role as a component of collective identity, defining lifestyles and being incorporated into political and economic structures. ${ }^{42}$ Yet, Islam's influence among the nomadic Kazakhs, Kyrgyz and Turkmen tribes was insignificant; they preserved their shamanistic culture and pre-Islamic socioeconomic and political identities until colonial rule.

Fourth, Central Asia's immediate post-independence societies were subjected to a severe ideological vacuum after seventy years of communism. Within a short period, different types of local and imported ideologies emerged based on ethnicity, culture and Islam. In most cases, governments encouraged certain Islamic or national trends, while simultaneously using the threat of 'Islamic extremism' to justify anti-democratic policies. This bureaucratic integration of Muslim clergy into the local administrative system by means of ideological projects was not 
new, having existed since tsarist times. Both it and the Soviet approach to Islam, which fluctuated between severe repression and periodic tolerance, negatively affected the development of Islam in the region. The infrastructure of Islamic higher education was undermined, for example, resulting in the absence of highquality Islamic clerics who might be more open to progressive and moderate ideas. Incompetent, but unconditionally loyal, clerics were usually appointed to high religious offices (muftiyats), keeping the Islamic discourse backward, immature and fanatic. This factor, as Mehrdad Haghayeghi observes, played an important role after independence in attracting small segments of the region's population to non-indigenous interpretations of Islam, including a variety of extremist ideologies. ${ }^{43}$ What I am trying to say here is that the long-established Central Asian approach to Islam at both state and individual levels became a crucial tool of identity construction as well as an instrument of authority, control and suppression of political opposition.

Overall, Central Asia's ruling elite failed to tolerate any negotiation or dialogue with the opposition, be it Islamic or secular. This policy of political exclusion caused a crisis of legitimacy for the ruling elites, exacerbated by corruption and nepotism. In future, this crisis of legitimacy could degenerate into political instability, further undermining prospects for democratisation. At the very least, this situation has prevented the development of a civil society and political parties, which are necessary requirements for a functioning democracy. ${ }^{44}$ In Kyrgyzstan, the opposition party leaders have been subjected to pressure or imprisonment. Both Uzbekistan and Turkmenistan have maintained a one-party state system, banning all organised political opposition. In Tajikistan, President Rahmonov has effectively marginalised the Islamic opposition, while in June 2002 Kazakhstan's parliament passed a law barring the establishment of new parties with fewer than 50,000 members and nationwide representation, making new opposition movements almost impossible to establish legally. ${ }^{45}$ This has arrested the formation of a viable counter-elite that could engage in discourse on policy options within Central Asia.

The next reason for the failure of democratisation in Central Asia relates to the phenomenon often defined as 'classic colonial syndrome.' The nature of political and economic relations between Moscow and Central Asia resulted in fragile economic systems and impotent political leadership in the latter region. Due to its colonial past, Central Asia became very much similar the raw-material-producing Third World, dependent on the export of natural products such as oil, natural gas and gold. Certainly, the original purpose underlying the Russian colonisation of Central Asia was economic: to acquire a reliable source of cotton for the expanding Russian textile industry and to gain access to new export markets. Soviet rule adhered to the same colonial policy of economic exploitation. The 
limited statistics available from Soviet times demonstrate the results of a cotton monoculture policy in Central Asia: by the end of the Soviet period, Central Asia was producing 92 percent of all Soviet cotton (the remaining 8 percent came from Azerbaijan), equal to 17 percent of global production. ${ }^{46}$ Kazakhstan provided coal for the industrialisation of Russia and, later, of the Soviet Union. Kazakhstan and Turkmenistan were the major oil and gas producers of the Soviet Union as well. Turkmenistan alone possesses the world's sixth largest reserves of natural gas and oil.

Soviet rule strived to provide stability in Central Asia in order to further its economic exploitation of the region. Nevertheless, the region remained underdeveloped compared to other parts of the Soviet Union. The bulk of the produce was sent to the centre. The mineral resources of the region, including coal and oil, were exploited haphazardly as part of a larger, centrally-planned Soviet economy. After independence, each Central Asian country needed to establish its own independent economic structure within an extremely short period of time. This, however, proved very difficult, causing inflation rates to rise, resulting in a decline in real income and wages, especially in Tajikistan, Turkmenistan and Uzbekistan. In addition, Central Asian countries did not have international economic and trade relations, as earlier all this had been handled by the central Soviet government. Even today, Russia is the largest economic partner of all the Central Asian countries, controlling the main routes for their oil and gas exports. The export of Turkmenistan gas and Kazakh oil, for instance, is determined by Russia's monopoly over the export pipelines. Consequently, Central Asia remains tightly bound to its former coloniser, while Russia maintains its influence in the region by encouraging internal conflicts and, at the same time, supporting the existing ruling structures. All this has limited democratic development in the region.

Lastly, US interest in Central Asia intensified sharply after the tragedy of September 11 due to its military campaign in Afghanistan. Right from the beginning of the Global War on Terror in 2001, Uzbekistan and Tajikistan, which border Afghanistan, offered basing facilities for US and other Allied forces. Turkmenistan also offered logistical assistance, as well as search and rescue provisions. Along with Kazakhstan and Kyrgyzstan, the Central Asian states provided over-flight rights and intelligence sharing. Kyrgyzstan's parliament voted to allow the US to use its airports for military and humanitarian activities in Afghanistan ${ }^{47}$ Such resilient military and political cooperation with the US strengthened the position of the existing authoritarian systems, allowing too tiny a space for the emergence of democratic opposition in Central Asia. 


\section{Conclusion and Policy Recommendations}

After this brief analysis of democratisation in Central Asia since the collapse of the Soviet Union, the paper suggests the following conclusions. First, the expected democratisation of the region failed due to both regional and international factors. Democratic transformations were never the ambition or desire of Central Asia's ruling elites, who have generally clung to power, either until they die or are forced out. Ironically, each Central Asian nation has the instruments of a democratic system, such as elections, legislatures, courts, laws and constitutions. These exist, however, in name only. In reality, decisions are made from the top, elections are rigged, courts and legislatures are filled with loyalists, and KGBstyle secret police continue to thrive. This article consequently suggests that the application of instruments of democracy alone cannot make nations democratic or provide well-being and justice for the people. Democracy is about achieving good governance; it should be viewed as a tool on the path towards achieving that aim, not as the main objective of governance.

Second, Central Asian countries have also failed to obtain full independence from Russia, finding themselves struggling with the consequences of their colonial past, often identified as 'classic colonial syndrome'. Their economic, political and social foundations are deeply moulded by Russian models, while colonialism has left many unsolved issues, such as ethnic tensions, racial inequality, centre-dependent economic systems and poverty. Moreover, most Central Asian countries did not desire their independence; national awareness was uncertain and the new ruling elites incapable of building new countries on the basis of democracy and liberalism. All five Central Asian countries have therefore been compelled to cultivate a sense of national awareness in an attempt to justify their formation and existence, resulting in what Robert Lowe calls a unique "laboratory" for the development of modern states and their ideology. ${ }^{48}$

Third, Islam played almost no role in the failure of democracy in Central Asia. Rather, Islam was completely marginalised both during the Soviet era and after independence. Its potential for establishing good governance has been ignored; if used at all by the regions secular dictators, it has been as an instrument of authority, control and political oppression.

Lastly, artificially implemented ideologies and structures cannot bring good results, especially without public demand or willingness to accept them. Thus, the question needs to be asked whether the Western model of democracy is the only right way to bring justice, well-being and happiness to humanity. Should every state in the developing world follow every small or big happening in the civilised Western world? This question requires deeper study. But what is important is that, even if Central Asia does not experience a 'democratic' transformation as 
understood in the West, there is urgent need for change, towards establishing human rights, security, justice and well-being for all citizens. These are the fundamental objectives of governance in Islam, suggesting the latter has a role to play in the region's future. Finally, the paper proposes the following policy recommendations:

- The evils of corruption, nepotism, tribalism, and political and economic injustice should be prevented by the authorities in Central Asia as extremely harmful for the well-being, stability and security of society. The governments of the region must guarantee the rights of every citizen under their authority, regardless of gender, age, religion, ethnicity or social background.

- The political elite in Central Asia should be more inclusive and open to opposition and alternative ideas. The will and rights of citizens should not be neglected or interfered with by internal or external players under the pretext of protecting 'democracy' or fighting against religious extremism. Democracy should be understood as a set of values and principles capable of establishing a just and moderate society, rather than as an exploitative set of instruments used to maintain power and authority.

- Muslim religious leaders, including 'ulama', muftis and the heads of various Islamic organisations in Central Asia, must concentrate on achieving a better understanding of the objectives and principles of governance in Islam.

- The region's media and educational systems should be actively utilised to promote a better understanding of governance and its objectives. This requires new textbooks and curricula to prepared for Central Asian youth, to build a better and safer future, whether based on a system called 'democracy' or something else.

\section{Notes}

* Elmira Akhmetova, a Tatar scholar from Russia, is Assistant Professor in the department of History and Civilisation, International Islamic University Malaysia. She has published a number of academic articles, book chapters and monographs on the issues of Islamic history, interfaith dialogue, Islamic political thought and civilisational studies. (Email: elmira@iium.edu.my and eakhmetova@yahoo. com).

1. The Economist, Democracy Index 2017: Free Speech under Attack (New York: The Economist Intelligence Unit Limited, 2018), 56.

2. Foundation for Democracy and Sustainable Development, 'What is Democracy,' 
Available at: http://www.fdsd.org/the-challenge/what-is-democracy (Accessed on: 25 July 2018).

3. A. Bayat, Islam and Democracy: What Is the Real Question? (Leiden: Amsterdam University Press, 2007), 59- 75.

4. Bernard Lewis, 'The Roots of Muslim Rage,' The Atlantic Monthly 266, no. 4 (1990) 22.

5. Salim Cevik, 'Myths and Realities on Islam and Democracy in the Middle East,' Estudios Politicos 38, no. 2 (2011): 126.

6. Samuel Huntington, The Clash of Civilizations and the Remaking of World Order (New York: Simon and Schuster, 1996), 220.

7. John O. Voll, 'Islam and Democracy: Is Modernisation a Barrier?' Modernization, Democracy and Islam, ed. Shireen T. Hunter and Huma Malik, (USA: Center for Strategic and International Studies, 2005), 83-4.

8. Ibid., 84 .

9. John L. Esposito and John O. Voll, Islam and Democracy (New York: Oxford University Press, 1996), 23-31.

10. Bayat, Islam and Democracy, 8; and Voll, 'Islam and Democracy,' 85.

11. Mohammad Hashim Kamali, 'Islam and Democracy,' Islam and Civilisational Renewal 4, no. 3 (2015): 437.

12. Ibid., 438.

13. Amina Chaudari, 'Face to Face with Bernard Lewis,' The Islamic Monthly. Available at: https://www.theislamicmonthly.com/face-to-face-with-bernardlewis (Accessed on: 27 July 2018).

14. Bayat, Islam and Democracy, 10.

15. Ibid., 13.

16. The Economist, Democracy Index $2017,87$.

17. Nate Schenkkan, 'Central Asia's Island of Democracy is Sinking,' Foreign Policy. Available at: https://foreignpolicy.com/2015/09/30/central-asias-islandof-democracy-is-sinking-kyrgyzstan (Accessed on: 29 July 2018).

18. Robert Lowe, 'Nation Building and Identity in the Kyrgyz Republic,' Central Asia: Aspects of Transition, ed. Tom Everett-Heath (London, New York: Routledge, 2003), 122.

19. Ibid., 127.

20. Joanna Lillis, 'Kazakhstan: Country Profile,' Freedom House. Available at: https://freedomhouse.org/report/nations-transit/2017/kazakhstan (Accessed on: 30 July 2018).

21. Nurseit Niyazbekov, 'Will Kazakhstan Ever Embrace Democracy?,' U.S. News. Available at: https:/www.usnews.com/news/best-countries/ articles/2016-10-24/will-kazakhstan-ever-embrace-democracy (Accessed on: 30 July 2018).

22. Tom Everett-Heath, 'Instability and Identity in a Post-Soviet World,' Central Asia: Aspects of Transition, ed. Tom Everett-Heath (London, New York: Routledge Curzon, 2003), 186.

23. Government of Uzbekistan, 'Facts and Details,' Available at: http:// factsanddetails.com/central-asia/Uzbekistan/sub8_3f/entry-4723.html (Accessed on: 1 August 2018).

24. Saltanat Berdikeeva, 'Organized Crime in Central Asia: A Threat Assessment,' 
China and Eurasia Forum Quarterly 7, No. 2 (2009): 84.

25. Government of Uzbekistan, 'Facts and Details,' Available at: http:// factsanddetails.com/central-asia/Uzbekistan/sub8_3f/entry-4723.html (Accessed on: 1 August 2018).

26. Ibid.

27. Everett-Heath, 'Instability and Identity in a Post-Soviet World,' 193-4.

28. Alex Stringer, Soviet Development in Central Asia, Central Asia: Aspects of Transition, ed. Tom Everett-Heath, (London, New York: Routledge Curzon, 2003), 149.

29. Mehrdad Haghayeghi, "Central Asia and Azerbaijan" Modernization, Democracy and Islam, ed. Shireen T. Hunter and Huma Malik, (USA: Center for Strategic and International Studies, 2005), 303.

30. Bruce Pannier, 'Why Does Tajikistan Need A Referendum?,' Radio Free Europe Radio Liberty. Available at: https://www.rferl.org/a/qishloq-ovozi-tajikistanreferendum-rahmon/27747496.html (Accessed on: 30 July 2018).

31. Freedom in the world, 'Tajikistan Profile,' Freedom House. Available at: https:// freedomhouse.org/report/ freedom-world/2017/tajikistan (Accessed on: 20 July 2018).

32. Bruce Pannier, 'Why Does Tajikistan Need A Referendum?

33. Freedom in the world, 'Tajikistan Profile.' Available at: https://freedomhouse. org/report/freedom-world/2017/turkmenistan (Accessed on: 20 July 2018).

34. Olivier Roy, The New Central Asia: The Creation of Nations, (New York: I.B. Tauris Publishers, 2000), 135.

35. Oliver Mark, 'Niyazov's Personality Cult,' Facts and Details. Available at: http://factsanddetails.com/central-asia/Turkmenistan/sub8_7a/entry-4805.html (Accessed on: 20 July 2018).

36. Casey Michel, 'Central Asia Still in the Democratic Doldrums,' The Diplomat. Available at: https://thediplomat.com/2017/02/central-asia-still-in-thedemocratic-doldrums (Accessed on: 20 July 2018).

37. Roy, The New Central Asia, 57.

38. Ibid., 56.

39. Tom Everett-Health, Central Asia: Aspects of Transition, 1.

40. Roy, The New Central Asia, 44.

41. Ibid.

42. Haghayeghi, "Central Asia and Azerbaijan," 294.

43. Ibid., 302.

44. Ibid., 303.

45. Ibid., 304.

46. Stringer, "Soviet Development in Central Asia," 149.

47. Fiona Hill, 'Contributions of Central Asian Nations to the Campaign Against Terrorism,' Brookings. Available at: https://www.brookings.edu/testimonies/ contributions-of-central-asian-nations-to-the-campaign-against-terrorism/ (Accessed on: 26 July 2018.)

48. Robert Lowe, Nation Building and Identity in the Kyrgyz Republic, Central Asia: Aspects of Transition, ed. Tom Everett-Heath, (London, New York: Routledge Curzon, 2003), 106. 